\title{
Women and Cultural Transformation: The Politics of Representation in the Novels of Bankimchandra Chattopadhyay
}

\author{
Sudip Roy Choudhury \\ Ph.D Research Scholar, Raiganj University, West Bengal, India. Orcid: oooo-ooo3-4833- \\ 7975. Email id: sudiproychoudhury6o@gmail.com
}

\begin{abstract}
This paper begins by arguing that Bankimchandra, a pioneering novelist and nationalist thinker of India, sought to contain the nineteenth century 'woman question' within his nationalist project of 'cultural transformation'. But this nationalist ideal is based on a gendered differentiation of the nation-culture into spiritual and material which has a far reaching implication in terms of his novelistic re-presentation of the nineteenth century 'woman question' and the 'hierarchical inclusion' of women in the political space of the nation. Hence, by contextualizing the works of Bankimchandra in a time of colonial encounter the present paper aims to bring out the complexities and paradoxes inherent in Bankimchandra's formation of the strategy of re-presentation of women and reform in several of his novels.
\end{abstract}

Keywords: Colonial encounter, cultural transformation, nationalist consciousness, gender, social reform.

\section{Introduction}

Born nine years after the abolition of the 'Sati' (1829), graduated a year after Sepoy Mutiny (1857), two years after the Widow Remarriage Act (1856), and died just three years after the demise of the great social reformer Iswar Chandra Vidyasagar(1891), Bankimchandra's life-span caught him in a crucial juncture of history when the 'woman question' ran in tandem with the emerging spirit nationalism. A man of great intellect and imaginative perception, Bankimchandra took his vocation as a literary artist for serious political purposes. Sri Aurobindo called him a "Rishi", one who had "divined" our linguistic and political need and "gave us the vision of the Mother" (Aurobindo, 1994, p. 6). He even made a sharp distinction between the earlier Bankim and the later - "The earlier Bankim was only a poet and stylist - the later Bankim was a seer and nationbuilder." (p. 4) But this division is somewhat arbitrary and it ignores the way in which Bankimchandra's position as a visionary nationalist thinker came to determine his perception of the nineteenth century 'woman question' and his novelistic representation of the ideal of femininity. So the present paper endeavours to examine the way in which Bankimchandra's perception of the pernicious aspects of colonial discourse had impelled his vision of a 'cultural transformation' where the question of ameliorating the real socio-economic condition of women is often sidelined in a strategic glorification of patibrata dharma and the ideal of renunciation.

\section{Women and Cultural Transformation}

(C) AesthetixMS 2020. This Open Access article is published under a Creative Commons Attribution Non-Commercial 4.o International License (http://creativecommons.org/licenses/by-nc/4.o/), which permits non-commercial re-use, distribution, and reproduction in any medium, provided the original work is properly cited. For citation use the DOI. For commercial re-use, please contact editor@rupkatha.com. 
But we must understand what was the ideal of 'cultural transformation'that Bankim upheld and how it had influenced his representation of the 'woman question' and ideal of femininity in his novels. Actually, Bankim's nationalist project of transformation is crystallized in the last phase of his career, in his conceptualization of anusilan dharma. It was theorized in Dharmattatva, epitomized in the character of Sri Krishna in Krishna Charitra and tried to be actualized in the then socio-economic condition in his last three novels Anandamath, Devi Choudhurani and Sitaram. It is a brilliant redefinition of tradition that aspires to imbibe the Western ideas of 'progress' and 'modernization' in the frame of the 'spiritual essence' of the nation. It claims that our 'true' spiritual tradition calls for the furthest fulfillment and perfect harmony of all our faculties (physical, intellectual, cognitive and aesthetic) through the practice of culture which is intimately connected with our dharma. This ideal gives a transformative agency to the nationculture and demonstrates that the colonial ascription of stereotype is not 'immutable' and can be transformed through the practice of 'culture'. This cultural ideal becomes very effective for two fundamental reasons - first, it destabilizes "the concept of 'fixity' in the ideological construction of otherness" (Bhabha, 1994, p. 66) which is the most important aspect of colonial discourse and second, it also solves

"A perennial problem ... in all nationalist thinking: how does one accept what is valuable in another's culture without losing one's own cultural identity?"(Chatterjee, 1986, p. 65)

But this ideal of 'transformation' through practice is trapped "within an essentialist typology of cultures" (Chatterjee, 1986, p. 73), where the 'material superiority' of the Western culture is counterpoised with the "spiritual or inner" sovereignty of the nation-culture. Bankim's appeal to imitate the 'good' material qualities of the West without ever contaminating the 'spiritual essence' of the nation is premised upon the gendered differentiation of the spheres of nation-culture into spiritual and material (Chatterjee, 1993). This binary classification of 'nationculture' not only helps establish its field of dominance and identity (i.e. its spiritual superiority) but also puts the burden of maintaining its 'innate sovereignty' and quintessential identity especially on the shoulders of women because women are the purveyors of this "inner/spiritual" domain. Any change or 'reform' in this domain, especially with tacit acceptance of the condescending judgment of colonial rule is tantamount to trivialize the nationalist claim to 'spiritual' supremacy and is, therefore, on the fence of a nationalist consciousness. This explains Bankimchandra's negative response to the questions of 'reform' with the help of colonial administration. In novels like Bisha Briksha (1873) and Krishnakanta's Will (1878), his portrayal of the tragic end of Kunda and Rohini can be read as a strong social interdiction to the idea of widow remarriage. Devi Chaudhurani's return to her polygamous husband and the author's exalted representation of her messianic manifestation of 'Anusilan Dharma' is also very problematic especially if we take into consideration the fact that Bankim spent considerable energy in the delineation of her education and her acquisition of harmonious perfection of all the faculties only to be sacrificed in a strategic celebration of patibrata dharma.

\section{3. 'Domestic Sphere' in the Colonial and Nationalist Politics}

But before going on to analyze the impact of this ideal of 'cultural transformation' on the representation of women in his novels, we must first situate the nineteenth century 'woman question' in the dynamics "of the cultural and ideological encounter between England and India"(Chakravarti, 1989, p. 37). How and why the concern with domesticity and woman emancipation became a central preoccupation of the colonial discourse and the politics of anticolonial nationalism should also become clear to us in order to make an honest appraisal of 
Bankimchandra's works. This specific bent of the social reform movement had its own reasons and compulsions.

Firstly, the colonial policy of non-intervention in the internal affairs of the Indian Society which was so apparent in Warren Hasting's 1772 enactment of the Hindu Personal Law had led to a virtual division of the spheres of domination. The personal sphere was left out by the colonial officials to be decided by the indigenous elites and their interpretation of the scriptures. This gave the traditional upper caste elites their own sense of power and privilege over the private sphere of their culture and as there was no intervention possible in the larger political and economic sphere, the indigenous elites, enthused by post-enlightenment modernising discourse directed their learning and agency on the "improvement" of this internal/private sphere of the society. This leads us to the relation of this social reform movement with the budding patriotic spirit of the nation.

Secondly, one of the major prongs of colonial scholarship had been its thrust on discovering and scrutinising the 'domestic life' of the subject population. It was argued that the civilizational advancement of a culture cannot be fully understood except through a full knowledge of the social custom and 'domestic life' of the subject population. It is well known that James Mill in his influential book The History of British India (1817) criticised the Indian civilisation on the basis of its barbaric treatment to women. Not only James Mill but a whole lot of Utilitarian and Evangelist scholars blasted the Orientalist myth of the ancient glory of the Indian civilisation largely on the basis of the abject status of women in the Indian culture. As Dipesh Chakrabarty states -

"The universalist indictment of this civilising discourse aroused in Bengali (male) social reformers of the nineteenth century a strong desire to participate in what was now seen as a world-community of peoples of nations...."( Chakrabarty, 1993, p. 4)

Thirdly, "this civilisational critique of India" (Chakrabarty, 1993) is closely allied with the colonial justification of the authoritarian Imperialism. Spivak's remark that "the white men are saving brown women from brown men" (Chakravorty Spivak, 2001, p. 2205) points to this justificatory politics of the colonial rule. Hence, when Rammohun Roy held up the figure of the Indian women as both victim and a repository of superhuman power and courage, he was not 'essentialising' Indian woman just because of his lack of "a more complex notion of female subjectivity" (Mani, 1989, p. 139) but because of his implicit endeavour to institute the nationalist 'difference' in the figure of the Indian woman. He was confirming the Orientalist proposition of the glorious ancient civilisation of India and its exceptionally gifted women. Actually, he was holding up the glory and identity of Indian civilization along with the need for its present reform. This aspect of clinging to the hoary tradition of the nation should not be overlooked in the whole debate of modernising the 'domestic sphere' in the nineteenth century because herein lies the connection of the domestic with the nation and its identity.

The above discussion makes us realise that the so-called conservative trend in Bankimchandra's dealing of the 'woman question' cannot be simply answered by assorting to describe him as a patriarchal upholder of tradition or simply as an anti-feminist. We must also take into consideration his nationalist consciousness that was engaged in a perpetual struggle with the colonial discourse and tried to project an alternative ideal of cultural transformation that can accommodate the nineteenth century 'woman question' into the fold of the nation-culture itself. 


\section{4. 'Women Question' and the Formation of the Strategy of Representation}

Bankimchandra's concern with the basic question of the nature and function or the proper sphere of women is profoundly discernable even in the very beginning of his career. His first novel, Rajmohan's Wife (1864), incidentally also the first Indian novel in English - though largely ignored in the previous century as possessing an archival interest only, seriously grapples with the most pressing questions of womanhood. The title of the novel itself is very intriguing. It points to the deep irony of a woman's life whose identity depends neither on the character and morality she possess nor on her charm but on her husband, even if he has no redeeming quality, even if he a criminal, a thief and a robber, a man of brutish taste and moral. The doctrine of equality most famously expounded by John Stuart Mill in The Subjection of Women (1869) and the doctrine of 'Separate Spheres' as articulated by John Ruskin in Of Queen's Garden (1865) are foreshadowed in the basic question that the novel poses - what will a refined and spirited woman do if she is noosed in a completely incompatible marriage with an uncouth and villainous criminal? Matangini's predicament is portrayed with acute empathy. A woman of refined sensibility, denied of all conjugal felicities, braves her solitary journey in a night rift apart by thunderstorm and lighting to save the property of her sister's husband with whom she is in love and the author describes her journey in terms that are reminiscent of Radha's avisar in Vaishnava poetry. The concept of "The Angel in the House" $(1854-62)$, as envisaged in a highly popular poem by Coventry Patmore, does hold little ground in such a desperate situation in which the heroine is exposed. Neither can we retain the same moral stringency regarding the duty and responsibility of women nor the airtight demarcation between the home and the world.

The water-tight category of the home, "the place of Peace; the shelter, not only from all injury, but from all terror, doubt and division..." (Ruskin, 2006, p. 1588) is rendered vulnerable to the external world as is 'the angel in the house', the wife, the woman who is tied to it by a deeply unsatisfactory marriage and is forced to expose herself to the elements to confess her 'illicit' love to her brother-in-law. Matangini's journey in the night takes an allegorical proportion in that it is the journey of a woman from home to the world.

The authorial anxiety is, however, discernable in the perfunctory and hasty end of the novel. Matangini is sent to her father's home and after that she dies an early death. The author cannot return her "to the conjugal space from which she has dislodged herself through an emotionally sanctioned but socially unforgivable act" (Chattopadhyay, 2009, p. 38). But keeping in mind the historically determined character of an art work, it must be acknowledged that in his very first novel Bankimchandra has put forward the most fundamental questions concerning women's role and place in society and though his resolutions are not without ambiguity, his genius lies in his unerring perspicacity to raise those questions.

Another ambitious and subtle imaginative conception that interrogated the validity of the intrinsic nature and sphere of womanhood and the influence of social institutions and ideologies in the formation of it is found in his second Bengali novel Kapalkundala (1866). In this excellent piece of lyrical beauty Bankim links the basic nature/nurture debate with the ideas and institutions of marriage, conjugality and womanhood. Kapalkundala is the story of an abandoned girl brought up in a forest by a Kapalik(a practitioner of Sakta Tantra) who wants to sacrifice her or to involve her in the practices of tantra sadhana when the propitious moment will come. She is neither a Miranda nor a Shakuntala who have exposure to the loving care and guidance of the elders. So when the force of circumstances leads her to marriage and to the ways of the civilized world outside, she is completely out of clue and Bankim does not flinch to endow her with a certain quality of rebelliousness. At a point in the novel Kapalkundala expresses her strong 
disapproval of the relations of servitude that marriage entails. In the Introduction to Bankim Upanyas Samagro edited by J.C. Bagal (1984), it is narrated that Bankimchandra once asked his brother Sanjibchandra and his friend Dinabandhu Mitra that if a girl was brought up in a forest and in the company of a Kapalik, completely outside the influence of society for the first sixteen years of her life and was brought in society only after marriage, how much change could happen in her character and behaviour. Dinabandhu Mitra didn't reply. However, Sanjibchandra replied that the girl will gradually forget her childhood in the company of her husband and children. This incident strongly registers Bankim's disbelief in the inherent nature of womanhood as it was the bone of contention in that period.

The question of 'separate spheres' is also symbolically raised in this novel because the tragedy issues forth from the time when Kapalkundala steps outside in the night to bring some herbs expecting her Sister-in- law's happy conjugality. There she meets the 'other' woman, Nabakumar's first wife, the shrewd Begum who may very well represent the outside world of politics and power. Moreover, the yearning for conjugality in Nabakumar's first wife in spite of all the power and prosperity she enjoys serves as a counterpoint to Kapalkundala's indifference to her husband's love and further establishes the fact of the ideological determination of gender. Besides, in both of these novels there are other variations of wifely miseries esp. instances of polygamy and Culin Pratha that further enriches as well as complicates the texture and vision of the novels.

Thus it can be very convincingly argued that from the very beginning of his career Bankimchandra was acutely concerned with the role and function of women in society and secondly, that he was discerning enough to understand, even before the publication of The Subjection of Women (1869), that there can be no inherent 'nature' of womanhood and wifely duties on the one hand and on the other, the internal and the external spheres are inextricably linked. But strangely enough this theory of 'separate spheres' as well as the doctrine of the intrinsic nature and function of womanhood will emerge strongly in the middle and last phase of Bankimchadra's career with very curious modifications. Prafulla's return to the domestic space is justified by the essentialist conception of gender which upholds the patriarchal ideology of the " intrinsic nature' of women that makes them fit for domestic purposes. To instantiate I quote from the penultimate chapter of Devi Choudhurani :

...When Prafulla had explained everything, Sagar asked, "Do you think you'll get used to housework now? After sitting on a silver throne wearing a crown of diamonds like a queen, will you be able to cope with washing the dishes and sweeping the rooms?

It's because I want to do those things that I am here," said Prafulla. "For this is precisely the right life for a woman. Women aren't born to rule. It's the family life you have described that is a hard duty; ...Any virtue greater than this? This is the kind of renunciation I want to embrace (Chatterji, 2010, p. 149).

This basic contradiction between the conception of gender in the very first of his novels and in the very last of his novels is explainable only when we take into account Bankimchandra's relation with colonialist discourse and his function as a nationalist thinker. The most dominant aspect of his work, especially of the last phase, is its pronounced preoccupation with the formation of a Hindu/ Indian cultural tradition that can accommodate the 'modernizing and progressive' aspects of Western culture without losing the 'essential identity' of the nation-culture. Thus his relation to colonial discourse is one of 'desire and derision', 'as anxious as it is assertive' (Bhabha, 1994, p.70). On the one hand, it involves a vituperative rejection of the justificatory discourse of 
colonial rule which derogated the Hindu/ Indian male as "effeminate" and the Indian culture as 'immature' and 'inferior' mainly by instantiating its "barbaric" traditions of oppression towards its women and lower caste men but on the other hand, it accepts and tries to imbibe the Western ideas of 'progress and modernization' in the very assertion of the cultural superiority of the Hindu tradition itself.

But who is to hold up the purity and greatness of this cultural and spiritual tradition? The men with their compulsory exposure to the outward world of colonial supremacy can barely be the emblem of this superiority. Furthermore, they are always open to the emasculating effects of the colonial discourse. So women became the most appropriate and tangible manifestation of the superiority of national culture and the domestic sphere became our true cultural essence that is not only 'different' but also superior to the Western culture. So any reform with the help of the condescending judgment of colonial rule must be discarded because if they are allowed to interfere in the 'inner core' of our culture, we shall not only lose the specificity of our cultural identity but also our claim to self-rule. The question of reform in women's position was thus predicated on the question, 'Who has the right to reform their position?' This was certainly one of the reasons of Bankimchandra's downright rejection of the reformist venture of Vidyasagar with the help of colonial administration. This negative approach to social reform is very much apparent in the novels of his middle phase, especially in Bisha Briksha (1873) and Krishnakanta's Will $(1878)$ and it is superfluous to add that these highly popular novels of Bankimchandra created a huge impact in building up a consensus against Vidyasagar's effort at introducing the widow remarriage.

But this barring of the colonial domination in the internal core of our cultural sphere, represented by home and women, is only negative in its isolation and withdrawal from the outer world of politics and power. It cannot withstand the thrusts of the egalitarian views of the colonial education and culture unless and until it is ennobled by a new agency and a new agenda.

Bankim's prose writings and novels of the last phase are wholly devoted to envisage this much needed agency and agenda for resistance. These novels, Anandamath (1882), Devi Choudhurani (1884) and Sitaram (1887) are meant to demonstrate the ideal of anusilan dharma in practice and in history and thereby institute the possibility of its recurrence. But these are historical romances based on the period of 'sanyasi rebellion' (179os) in India and Bankim spent very little effort to strictly adhere to historical facts. The historical period is used merely as a structural façade, a way to avoid the colonial censor and persecution. It should be kept in mind that Dinabandhu Mitra's Nildarpan(1860) was banned and disciplinary action was taken against it. Bankim very smartly instills the spirit of freedom and sacrifice for the country without directly referring to the present political scenario. The imaginative history also acts as a nationalist's wish fulfillment for a nation without history. In many of his prose essays, Bankim lamented the lack of true historical account of the Hindus and referred to the politics of the European and Muslim historians in delineating Indian/ Hindu culture and character in a negative light. Thus it also helped in his larger programme of the recovery of the Hindu ideal in History which he did in his longest work, Krishna Charitra.

But what is distinctive in these novels is Bankim's passionate portrayal of women. Women like, Prafulla in Devi Choudhurani, Shanti in Anandamath and Shri in Sitaram are characters of bold strokes that need real imaginative lift for their conception. They are invincible and almost archetypal in their affective valence. They break the boundaries of reality without the slightest impairment of their aesthetic appeal. The remarkable element in the portrayal of these characters is the ideal they convey or stand for. The ideal of the infinite power of their 'being' that can work 
for a cause and inspire it. But the process of 'becoming' is more important because it destabilizes the notion of 'fixed origin' and celebrates the transformative power of anusilan dharma. It also helps maintain verisimilitude to reality by referring to the material constraints they face. They are all abandoned women without proper means of livelihood. The thrust of their appeal lies in their effort at transcendence from those delimiting circumstances. They make self-assertion through self-denial. Their transcendence of situational duress is, in a sense, tantamount to suppress the painful reality of their existence through the practice of austerity and self sacrifice which is extolled as their 'real' power. For instance, Prafulla undergoes five years of rigorous training under the tutelage of Bhabani Pathak and Bankim exerts considerable energy in outlining the specifics of her education. The whole chapter-15 in the $1^{\text {st }}$ part of the novel concentrates on this purpose -

For the first year, Bhabani Thakur arranged for her to eat coarse rice seasoned with rock salt, ghee, and green bananas - nothing else. Nishi had to eat the same food. But even this didn't worry Prafulla: she usually had less to eat in her mother's house. But in one matter Prafulla disobeyed Bhabani Thakur. On ekadashi day she would insist on eating fish. (Chatterji, 2010, p. 78).

This particular reference of disobedience is paradigmatic because it helps to illustrate Bankim's ambivalent portrayal of women, esp. in his last novels. Prafulla makes it a point to eat fish only in the ekadashi (the Hindu ritual of Fasting) because through this practice she wants to show that she is not a widow. She is a married woman. This particular aspect of disobedience registers the use of the concept of "fixed origin" or 'essence' of womanhood in a chapter that is devoted completely to uphold the idea of 'transformation through practice'. Shanti, in Anandamath, and Shri in Sitaram also go through this process of practice (though in different ways) which transform their being, esp. their capacity of endurance and sacrifice. And these qualities are foregrounded again and again in hyperbolic terms. But in this process of practicing endurance and sacrifice, they never dream to forget their essential patibrata dharma. In fact, their being Sati and patibrata help them undergo with ease all the trials and tribulations of adversity. They are the objectified projection of male imagination. The omniscient author hails them as saviors of the time and asserts their essential presence from time immemorial -

So come now, Prafulla! Return to our world once more and let us behold you. Why don't you confront this society of ours and say: "I am not something new; I go back in time. For I am that very same voice of the past. How often have I come to you, and you have forgotten me, and so I have come again. "To protect the good, to destroy the wicked, and to establish the right order, I take birth in every age. (Chatterji, 2010, p. 151)

Thus the novels heralded in trumpet tongue the advent of the 'New Women' in whom will be manifested the transformative power of anusilan dharma through the imbrications of the qualities of 'modernity' and 'progress' without ever losing their quintessential cultural core, their unchangeable and 'fixed' essence of chastity, devotion and sacrifice.

The formation or representation of the 'New Woman' served important practical purposes and was designed to meet the nationalist need of the time. It imposed a vision of the social world where women can have the equal share of merit by the dint of their sheer effort and quality of self-sacrifice and chastity. Thus it helped in containing the 'woman question' in the 'inner domain' of the nation-culture. It endeavoured to offer at least an appearance of meaning and significance to the wretched lives of the Hindu women within the fold of their own culture. Whatever it may be, it gave them the appearance of agency and thereby discouraged them to cross the boundaries of their own culture. The proselytizing zeal of the missionaries, the Westernizing influence of Bhramo Samaj and the Young Bengal should be kept in mind here. It 
also tried to uphold not only the power and dignity of the indigenous women but also of indigenous culture and its patriarchal order.

But it is also true that Bankim sanctions a revolutionary role for women in the national struggle for liberation and it opens up new vistas for the long-confined women of the nation. His tireless negotiation between the contradictory compulsions of nationalism and 'woman emancipation' opens up significant possibilities of transcending the watertight categories of public/private, inner/outer sphere on which is premised his nationalist project of cultural selfdetermination. As Jasodhara Bagchi in her adept analysis of Anandamath observes, "It is in creating Shanti that Bankim delinks wifehood from the enclosed space of domesticity." She further comments that

"This dynamic uplift that Bankim gives to the traditional quietist role of a sahadharmini greatly contributes to the nationalist euphoria of the novel that overwhelms any loyalist message that Bankim may have introduced in it."(Bagchi, 1985, p. 61)

\section{Conclusion}

Indeed, the deep ambivalence that fractures Bankimchandra's response to the 'women question' is rooted in his nationalist consciousness. His essentialisation of women's role has within it the typical nationalist assertion to 'difference' and dignity of the spiritual sphere of the nationculture. And this essentialisation happens not because of his inability to understand the fundamental falsity of any essentialist claim to 'difference' but because of his strategic manipulation of essentialism itself. On the one hand, we find in him the negation of ideas of 'reform' and 'modernization' in the sphere of the 'inner/spiritual" domain of culture represented by women and on the other hand, his nationalist consciousness envisions the symbolic carriers of this domain of culture as powerful as to cross the limits of her 'boundary' and encroach triumphantly in the outer world of politics and action. In fact, the theory of Anusilan finds its perfect vector only in his women characters. Prafulla in Devi Choudhurani, Shanti in Anandamath, and Shri in Sitaram are the real exemplars of the concept of Anusilan. These women bear the brunt of nationalist 'transformation' far more than any men. In comparison, the male characters from Sitaram to Vabananda are all seen to be fallible and often absolved of their hard responsibilities. Their heroism often becomes shallow and is not without its pitfalls.

\section{Funding Disclosure}

This work is not supported by any institutional funding.

\section{Acknowledgement}

I would like to thank my PhD supervisor, Dr. Nirjhar Sarkar for his unfailing help and guidance in writing the paper.

\section{References}

Aurobindo, S. (1994). Rishi Bankimchandra. In B. Chatterjee (Ed.), Bankimchandra Chatterjee: Essays in Perspective (pp. 4-6). New Delhi, India: Sahitya Academy.

Bagchi, J. (1985). Positivism and Nationalism: Womanhood and Crisis in Nationalist Fiction Bankimchandra's Anandmath. Economic and Political Weekly, 20(43), WS58-WS62. 
Bhabha, H. (1994). The other question: Stereotype, discrimination and the discourse of colonialism. In The Location of Culture (pp. 66-84). London and New York: Routledge.

Chakrabarty, D. (1993). The Difference: Deferral of (A) Colonial Modernity: Public Debates on Domesticity in British Bengal. History Workshop Journal, (36), 1-34. http://www.jstor.org/stable/4289250 Accessed: 12-12-2017 08:54 UTC

Chakravarti, U. (1989). Whatever Happened to the Vedic Dasi? Orientalism, Nationalism and a Script for the Past. In K. Sangari \& S. Vaid (Eds.), Recasting Women (pp. 35-114). New Delhi: Zubaan.

Chakravorty Spivak, G. (2001). Can the Subaltern Speak? In V. B. Leitch (Ed.), Norton Anthology of Theory and Criticism (pp. 2197-2208). New York. London: W.W. Norton \& Company, Inc.

Chatterjee, P. (1986). The Moment of Departure: Culture and Power in the Thought of Bankimchandra. In Nationalist Thought and the Colonial World: A Derivative Discourse. London: Zed Books.

Chatterjee, P. (1993). The Nation and Its Women. In The Nation and Its Fragments: Colonial and Postcolonial Histories (pp. 116-134). Princeton, New Jersey: Princeton UP.

Chatterji, B. (2010). Debi Chaudhurani, or The Wife Who Came Home (J. J. Lipner, Trans.). New Delhi: Oxford UP.

Chattopadhyay, B. (2005). Bankimchandra Omnibus: Volume - 1 (R. Chakravarty, M. Maddern, S. N. Mukherjee, \& S. Guha, Trans.). Penguin.

Chattopadhyay, B. (1984). Bankim Rachanabali, Vol. I. J. Bagal (Ed.). Kolkata-9: Sahitya Samsad.

Chattopadhyay, B. (1954). Bankim Rachanavali II. J. Bagal (Ed.). Kolkata: Sahitya Samsad.

.Chattopadhyay, B. (2009). Rajmohan's Wife. M. Mukherjee (Ed.). Navi Mumbai: Penguin Books.

Mani, L. (1989). Contentious Traditions: The Debate on Sati in Colonial India. In K. Sangari \& S. Vaid (Eds.), Recasting Women: Essays in Colonial History (pp. 115-165). New Delhi: Zubaan.

Ruskin, J. (2006). Of Queens' Gardens. In S. Greenblatt (Ed.), The Norton Anthology of English Literature (8th ed., pp. 1587-1588). New York. London.Bate, J. (1999). Shakespeare and original genius. In P. Murray (Ed.), Genius - The History of an Idea. New York: Basil Blackwell. 76-97

The author is currently a PhD Research Scholar in the Department of English, Raiganj University, India. His board area of Ph.D research is the dynamics of the nation-gender copula in nineteenth entury Bengal. His paper has been published in UGC Care-listed journal Middle Flight (issn 23197684). He has also presented his paper in an International Conference organised by Utkal University. 